\title{
DISIPLIN: SIKAP DAN PERILAKU TAAT
}

\author{
Dede Suleman \\ Universitas Bina Sarana Informatika, Jakarta \\ dedeeesuleman@yahoo.co.id
}

Submitted: $14^{\text {th }}$ Sept $2019 /$ Edited: $12^{\text {th }}$ December $2019 /$ Issued: $01^{\text {st }}$ January 2020

Cited on: Suleman, Dede. (2020). DISIPLIN: SIKAP DAN PERILAKU TAAT.

SCIENTIFIC JOURNAL OF REFLECTION: Economic, Accounting, Management and

Business, 3(1), 11-20.

DOI: $10.37481 /$ sjr.v3i1.111

https://doi.org/10.37481/sjr.v3i1.111

\begin{abstract}
The leader is happy, when he sees an orderly employee at work, systematic in solving problems, listening to orders, pay attention to standards, be careful when working, respect the opinions of others, work together as a solid team, and so on. Indeed that is discipline. This research seeks to dig up information, obtain data, analyze findings, provide conclusions and suggestions. To prove this, a series of scientific methods was carried out using a quantitative approach and regression analysis. Data collection techniques using questionnaires and random samples. This finding suggests, that a person is said to be disciplined if his attitude is in accordance with his behavior. His behavior is measurable proof of discipline, and has implications for organizational goals.
\end{abstract}

\section{Keywords : Discipline, Attitude, Behavior}

\section{PENDAHULUAN}

Sebagian orang mengatakan disiplin adalah aturan, sebagian lain memahami sebagai hukuman atas kebebasan, sebagian lain menerjemahkan sebagai nilai sikap dan perilaku, dan sebagian lain melihat sebagai pedoman atau petunjuk. Terlepas dari itu semua, pegawai disiplin lebih disukai perusahaan, pegawai patuh lebih diperhatikan pimpinan, pegawai disiplin menjadi contoh bagi orang lain, pegawai disiplin lebih minimal risiko (Helwig, et al., 2014).

Terjemahan dari disiplin tidak terlepas dari apa yang disampaikan di atas, disiplin memang aturan. Artinya disiplin mengatur segala sesuatu yang berkaitan dengan aktivitas organisasi, termasuk di dalamnya waktu, biaya, tenaga, pikiran, sikap, dan perilaku yang dibutuhkan. Marchbanks et al (2015) mengemukakan disiplin adalah komponen atau asosiasi dari demokrasi organisasi, bahwa pegawai harus bekerja 
bersama, bekerja terarah, bekerja prioritas, bekerja sehat, bekerja santun, dll di bawah kendali disiplin. Disiplin hanya simbol keberartian kerja, adanya aturan bukan untuk mengekang dalam konotasi buruk, tapi untuk mengarahkan pada jalan yang mudah, menuntun dengan pengetahuan agar jelas arah tujuan, dan meyakinkan diri bahwa apa yang dilakukan adalah benar (Lindblom-Ylänne, et al., 2006; Kinsler, 2013; USÓ-JUAN, 2006).

Laird, et al (2008), tujuan itu penting untuk dicapai, maka caranya adalah disiplin, fokus dan sabar pada aturan akan menghantarkan pada tujuan. Disiplin itu sistem instruksi yang mampu mendorong setiap orang untuk bekerja sesuai ketentuan, disiplin mekanisme untuk bersikap dan berperilaku melakukan yang benar. Organisasi tidak hanya melihat tujuan di depan, ia melihat realitas, bagaimana tujuan itu dicapai (Babcock, 2009). Pimpinan mengarahkan semua pegawai dengan aturan, dengan itu ia kuat dalam waktu yang lama (Lacoe \& Steinberg, 2018)

Bagi pimpinan tugas yang mungkin rutin dilakukan adalah memastikan bagaimana disiplin itu dilaksanakan setiap saat. Ia wajib memantau kehadiran, proses pengerjaan, laporan dan lain sebagainya. Tentu pimpinan melihat bagaimana sikapnya apakah sudah sesuai dengan yang dimaksud disiplin, apakah ia menyenangi aturan, apakah ia menerima dengan penuh semangat, atau justru ia terbebani. Namun bagi pimpinan, itu bukan soal, bahwa pegawai berkewajiban taat. Ia tidak bisa mengelak atas perintah, bahwa ia bekerja harus mengikuti aturan pimpinan. Pimpinan mengendalikan semua fungsi organisasi, karena ia bertanggung jawab atas itu.

Terlebih tuntutan organisasi terhadap pimpinan sangat tinggi, maka optimalisasi peran adalah menggunakan aturan disiplin. Pegawai akan cenderung takluk, ia tidak dapat berkilah jika soal aturan telah diberlakukan, meskipun terkadang pimpinan salah, namun aturan tidak bisa dilanggar. Bagi pegawai aturan adalah mutlak, tidak ada penafsiran tentang aturan disiplin, pegawai hanya wajib untuk bekerja sesuai SOP, bekerja sama, menunjung prosedur, melihat strategi sebagai alternatif, meninggalkan keburukan yang merusak sistem.

Hawken, et al (2007) disiplin memiliki dua mata pisau, ia menyakitkan untuk dilanggar dan tajam untuk mencapai tujuan. Perilaku dan sikap harus menyatu dengan disiplin itu. Disiplin yang telah dijelaskan organisasi secara rinci, mengenai sikap tanggap, bertanggung jawab, antusias, totalitas, dll. 
Wujud sikap disiplin adalah pengendalian diri. Pimpinan merasa senang ketika ucapannya didengarkan, ia akan perhatikan ketika ucapannya dicontoh, ia akan memperjuangkan dan mempertahankan pegawai ketika perintahnya berubah menjadi tindakan. Pegawai membebaskan dirinya dari penolakan atau penghindaran, ia realistis dalam sistem organisasi, bahwa posisinya adalah operasional yang harus mendengarkan perkataan CEO. Sikap ini berguna bagi kondusfitas perusahaan. Dengan kata lain, sikap disiplin harus merujuk pada ketaatan, apa pun yang menjadi perintah harus dilakukan, tidak ada kata dipikirkan atau dipelajari, pimpinan memaksa pegawai hanya untuk bekerja sesuai perintah. Sikap taat merujuk pada finalisasi disiplin, artinya puncak dari sebuah aturan atau perintah adalah kesukarelaan pelaksanaan (ketaatan).

Davis, et al (2006), ketaatan adalah jendela bagi pegawai, yang dapat membantu menormalkan sirkulasi angin dari dalam dan luar. Artinya, dengan sikap taat pegawai berada pada posisi yang bebas dan terkendali, ia mampu menunjukkan kendali diri yang pas pada struktur organisasi, dan bisa mempengaruhi persepsi organisasi pada keadaan yang dibutuhkan (angin masuk) berupa ide atau konsep, berupa strategi atau inovasi, berupa kreativitas, alternatif, dan lain-lain.

Bellizzi \& Hasty (2001), sikap patuh harus menghasilkan perilaku baik, dengan mengerjakan SOP secara presisi, menggunakan kompetensi maksimal dalam menyelesaikan tugas, dan menggunakan kecerdasan serta pengalaman untuk menunjukkan hasil yang baik. McReynolds \& Wasserman (2008) perilaku disiplin itu membuktikan pentingnya atau alasan mendasar adanya disiplin, ini menguatkan pimpinan untuk melanjutkan aturan dan membuat yang lebih baik. Karena perilaku disiplin itu berpengaruh terhadap hasil kerja. Setidaknya disiplin membuktikan pegawai profesional, mereka berintegritas, mereka layak dipercaya, mereka ahli, mereka patut diapresiasi, dan lain-lain. Maka dari pada itu disiplin harus dipertahankan (Bower-Russa, et al.,2001).

Qualls (2014), hal yang berarti dari disiplin adalah hendak mencapai penerimaan tanggung jawab. Pernyataan ini menegaskan, bahwa disiplin tidak berpengaruh secara langsung terhadap tujuan, namun ia membenahi proses dan menguatkan sistem pencapaian tujuan. Dengan demikian, disiplin dapat dikatakan sebagai variabel moderasi yang menghantarkan organisasi pada keberhasilan. 
Vol. 3, No. 1, January 2020

\section{LANDASAN TEORI}

Kata disiplin merupakan kata benda, artinya sesuatu yang tidak bernyawa. Maka dari asal kata tersebut, sesungguhnya kata disiplin terucap ketika seseorang menghendaki satu ketentuan yang dibuat, bisa dengan kesepakatan (jika kelompok) dan atau individu (privasi) guna mengendalikan perilaku manusia yang terlibat. Dengan kata lain, dalam organisasi lahirnya aturan dimaksudkan untuk mengatur pegawai dalam bekerja, tanpa terkecuali. Sekecil atau sebesar apapun aktivitasnya di dalam organisasi, serumit atau sesederhana apapun masalahnya, kerja kelompok atau individu, dan lainlain tidak terlepas oleh aturan (disiplin).

Pada dasarnya, disiplin lahir karena organisasi memahami setiap pegawai/ karyawan berbeda, maka sangat mungkin terjadi perselisihan, pemikiran, dan pelaksanaan. Sementara organisasi memiliki tujuan yang hendak dicapai, maka perusahaan berpikir bagaimana melihat sisi positif pegawai dengan segala karakteristiknya melalui disiplin. Sehingga pada perkembangannya disiplin memiliki makna mengarahkan pekerja untuk mengenal apa alasannya diterima bekerja, apa perannya, apa tugasnya, apa haknya, apa fasilitasnya, siapa rekannya, siapa pimpinannya, dan lain sebagainya, dengan demikian dimungkinkan seluruh anggota perusahaan seiring dan seirama di dalam memajukan perusahaan.

Hal yang tidak dipungkiri dari disiplin, sebagaimana dikemukakan di atas adalah mengendalikan sikap dan perilaku. Tentu perusahaan tidak mengetahui latar belakang pekerjanya, ia meyakini bahwa setiap orang yang diterima pasti memiliki sikap yang baik dan dapat berperilaku sesuai dengan keinginan perusahaan. Arti sesuai bukan berarti perusahaan memonopoli atau mengendalikan pegawai dalam konotasi sosial, melainkan dalam aspek manajerial, yakni seni di dalam bekerja. Keselarasan sikap menjelaskan tingginya prinsip dan nilai-nilai, sedangkan perilaku adalah pembuktian nyata dari asas dan nilai tersebut. Tentu sikap tanggung jawab terhadap waktu harus dibuktikan oleh kehadiran tepat waktu, sikap komitmen harus dibuktikan oleh hasil kerja yang tuntas, sikap jujur harus dibuktikan oleh konsekuensi, sikap patuh harus dibuktikan oleh kesigapan, sikap hati-hati harus dibuktikan oleh kecermatan kerja, dan lain sebagainya, sebagai wujud disiplin yang utuh.

Tentu pimpinan menghendaki perintahnya ditaati, dengan didengarkan secara seksama pada saat disampaikan dan segera dikerjakan dengan rasa hormat. Mungkin 
secara teknis sikap dan perilaku disiplin pada awalnya tidak berdampak langsung pada hasil kerja, namun ia mempengaruhi emosionalitas organisasi, di mana pimpinan terkesan dan pegawai lain segan. Pada tahap selanjutnya disiplin baru benar-benar berpengaruh terhadap proses pelaksanaan tugas, bahwa sikap dan perilaku taat akan aturan dan prosedur akan melahirkan pemikiran untuk bekerja dengan benar, kemudian lahir kompetensi yang maksimal, selanjutnya ada orientasi pada hasil yang lebih baik.

Kadang kala, disiplin menuntun pegawai sampai pada hal-hal terkecil. Di mana ada rasa hati-hati yang menyelimuti jiwa, sehingga melahirkan perilaku cermat, teliti, cekatan, dan pengawasan melekat yang mengupayakan segala sesuatu dilakukan sempurna dengan menepikan segala kemungkinan risiko. Indraputra \& Sutrisna (2013) mengatakan bahwa disiplin wujudnya aturan namun sesungguhnya tujuan dari disiplin adalah sikap dan perilaku.

Suwondo \& Sutanto (2015), yang menarik ternyata disiplin berkaitan dengan semangat kerja. Artinya, ketika seseorang tepat waktu, prosedural dalam bekerja, cermat, dan lain-lain sesungguhnya ia sedang bersemangat, maka tidak jarang dari sana tercapai suatu kinerja yang baik. Kenyataan ini menegaskan bahwa sesungguhnya suatu sikap disiplin merepsentatifkan beberapa variabel lain di dalam bekerja. Singer \& Smith (2013) mengatakan yang paling dekat dengan disiplin adalah motivasi dan yang menjadi target adalah kinerja. Disiplin hadir untuk menjadi semangat dalam keteraturan, konsistensi, dan kesesuaian agar hasil kerja sesuai dengan standar yang ditetapkan. Meskipun, pada pelaksanaannya tidak mudah menerapkan disiplin dan menyadarkan orang berdisiplin.

YE \& LIU (2009), kajian disiplin itu dalam, karena menyangkut sikap dan perilaku yang rinci. Bukan karena perusahaan yang besar atau hebat, namun karena kekhasan pegawai sebagai manusia berakal. Oleh karenanya, selalu lahir perusahaan perusahaan besar seperti Google, Amazon, Microsoft, McDonald, KFC, dan lain-lain dikarenakan disiplin mereka kompleks. mereka mengatur segala hal yang unik terkecil sekalipun yang itu merupakan bagian dari sikap dan perilaku pegawainya, dan itu sensitif terhadap pencapaian masa depan. Dengan kata lain, disiplin itu mengambil bagian penting dalam aktivitas organisasi. Perannya mengatur pegawai untuk konsisten pada koridor yang telah ditetapkan. 


\section{METODE PENELITIAN}

Penelitian ini melibatkan kurang lebih 200 pekerja di sektor retail yang berasal dari kota Jakarta dan Tangerang serta beberapa dari kota lain (Depok, Bogor, dan Bekasi). Untuk menguji data yang diperoleh melalui penyebaran kuesioner, maka digunakan metode kuantitatif dan analisis regresi linear. Metode kuantitatif dimaksudkan sebagai landasan konstruktif dari penelitian ini. sedangkan analisis regresi digunakan sebagai cara di dalam menganalisis suatu data, sehingga dapat disajikan suatu informasi yang mudah dipahami dan dikemukakan temuan-temuan sebagai bahan rujukan.

\section{HASIL PENELITIAN}

Sikap disiplin diajukan dengan 3 indikator, yaitu patuh pada perintah pimpinan, menaati aturan, patuh pada kebijakan organisasi. Dari ketiga indikator tersebut, sikap patuh pada pimpinan mendominasi, di mana pegawai memandang dari sudut hubungan yang membuatnya sulit untuk mengabaikannya. Terlebih dalam keseharian pegawai selalu berinteraksi dengan pimpinan, maka rasanya tidak ada celah untuk tidak menghormatinya, tidak mungkin untuk tidak patuh atas segala perintahnya. Oleh karena keadaan tersebut, pegawai lebih bisa merasakan keberadaan pimpinan, lebih terikat emosionalnya yang kemudian merubah sudut pandang dan perlakukannya.

Adapun menaati aturan dan patuh terhadap kebijakan organisasi dipersepsikan pada tahap normatif. Di mana tingkatannya tergantung pada setiap pegawai, dan itu dipengaruhi oleh latar belakang dan karakteristik masing-masing. Ada yang memang sejak awal pegawai telah terbiasa dengan aturan, maka ia lebih baik dalam hal penerapannya, ada pula pegawai yang butuh penyesuaian dengan aturan karena alasan karakteristik atau pemahaman, ada pula pegawai yang kurang memahami namun sigap dalam pelaksanaan, dan lain sebagainya.

Perilaku disiplin diajukan dengan 2 indikator utama, yaitu perilaku benar dan perilaku baik. Perilaku benar adalah perbuatan kerja, sedangkan perilaku baik adalah perbuatan sosial. Dalam bekerja kedua perilaku tersebut melekat, ketika seseorang melaksanakan tugas sudah barang tentu ia akan bekerja sesuai prosedur, kebijakan, dan perintah pimpinan. Namun di sela-sela perilaku tersebut pegawai juga akan 
menggunakan perilaku baik, misalnya pada saat berinteraksi dan berkomunikasi, tentu pegawai akan menggunakan cara-cara sosial.

Sikap disiplin berpengaruh signifikan terhadap kedisiplinan dengan koefisien regresi sebesar 0,430. Sebagai dimensi dan sekaligus indikator bagi kedisiplinan sikap merupakan asas seseorang pegawai dikatakan disiplin atau berdisiplin. Sulit menilai seseorang yang tidak menunjukkan sikap patuh sebagai orang yang disiplin, pimpinan tidak melihat pegawai sebagai sosok disiplin jika kurang perhatian pada saat disampaikan tugas, organisasi akan mengevaluasi sikap-sikap yang membangkang atas kebijakan. Keadaan ini menjelaskan, bahwa hal pertama seseorang harus bersikap, dan sikap tersebut adalah patuh pada perintah pimpinan, menaati aturan, patuh pada kebijakan organisasi.

Perilaku disiplin dapat menjelaskan kedisiplinan dengan nilai pengaruh (regresi) sebesar 0,280. Temuan ini sejalan dengan praktek di lapangan, seorang pegawai harus bekerja sesuai aturan maka ia dapat dikatakan sebagai pegawai yang disiplin, seorang pegawai harus hadir tepat waktu tanpa alasan apapun, seorang pegawai harus menyelesaikan tugas sesuai jadwal, seorang pegawai harus bekerja sesuai cara-cara organisasi (di kantor, menggunakan peralatan yang ada, berinteraksi dengan pegawai lain, dll), dan tidak diperkenankan berperilaku melawan aturan atau kebijakan. Sesungguhnya organisasi melihat perilaku pegawai sebagai suatu penilaian normatif dan etis, jika mereka bekerja namun tidak saling membantu atau bekerja namun merugikan tim lain maka akan ada tindakan tegas dari pimpinan.

Temuan di atas menegaskan kemenarikan disiplin. Bahwa disiplin itu perlu dibuktikan berupa sikap dan perilaku, karena keduanyalah yang berarti bagi kinerja, yang berarti bagi perusahaan, yang berarti bagi pelanggan, yang berarti bagi pencapaian tujuan organisasi, dan lain sebagainya. Disiplin harus berwujud tidak boleh abstrak di dalam pikiran, disiplin harus menjadi karakteristik/ kepribadian, pribadi yang taat pada perintah, pribadi yang sigap dalam pelayanan, pribadi yang bertanggung jawab dengan tugas yang diemban, pribadi yang menerima konsekuensi dan menyelesaikan permasalahan yang ditimbulkannya, dll. Dengan kata lain, disiplin bagi perusahaan adalah alat mengarahkan pegawai untuk bekerja sesuai ketentuan, terlepas apapun latar belakang pegawai. 


\section{KESIMPULAN}

Sikap patuh kepada pimpinan dipersepsikan paling tinggi. Artinya, bagi pegawai pimpinan itu nyata dalam keseharian di kantor, maka tidak ada alasan untuk mengabaikannya, terlebih pimpinan juga manusia yang memiliki kedudukan tingggi di dalam organisasi, maka sudah sepantasnya para pegawai menghormatinya. Oleh karena itu pegawai juga menyadari, bahwa perlakukan di dalam menghormati pimpinan sangat berbeda dengan perlakukan di dalam menghormati aturan. Mengingat aturan lebih bersifat personal, sehingga tingkat penghormatannya kembali kepada masing-masing individu pegawai.

Perilaku benar lebih dipersepsikan baik ketimbang perilaku baik. Adapun yang dimaksud perilaku benar dalam penelitian ini adalah, suatu perbuatan kerja yang sejalan dengan prosedur atau kebijakan atau aturan yang berlaku. Sedangkan perilaku baik adalah suatu perbuatan normatif pada umumnya seperti komunikasi dan interaksi. Dengan kata lain, di dalam bekerja diperlukan suatu perbuatan khusus, yaitu perilaku kerja. Di mana setiap tindakannya berlandaskan pada aturan dengan suatu orientasi pencapaian target atau prestasi yang telah ditetapkan.

Dari perhitungan statistik diketahui sikap lebih dominan terhadap penjelasan disiplin. Artinya seseorang dikatakan disiplin, maka hal pertama yang diakui adalah sikapnya. Bagaimana ia menghormati waktu, bagaimana ia mendengarkan instruksi pimpinan, bagaimana ia bertanggung jawab atas tugas yang diemban, bagaimana ia menghargai timnya, dan lain sebagainya. Dengan demikian sesungguhnya pegawai tersebut telah mendapati dirinya sebagai orang yang berdisiplin. Ia telah mampu menerapkan nilai-nilai disiplin dalam kehidupan bekerja, dan sesungguhnya yang demikian itu yang dikehendaki dari adanya suatu aturan.

Sedangkan perilaku kerja, secara statistik dapat menjelaskan disiplin. Ini artinya, disiplin itu paket antara sikap dan perilaku. Bahwa tidak benar seseorang patuh namun tidak bekerja, seseorang menghormati waktu tapi terlambat, seseorang berkomitmen namun mengabaikan SOP, dan lain-lain. Perilaku adalah bukti sikap disiplin, perilaku adalah wujud sikap disiplin, perilaku adalah ukuran sejauh mana sikap seseorang terhadap kedisiplinan, dan bahkan perilaku menunjukkan seberapa baik tingkat disiplin seseorang dari berbagai aspek, termasuk keluasan pengetahuan, keluasan pengalaman, kecerdasan sosial, kebaikan karakter, dan kebaikan organisasional. 


\section{DAFTAR PUSTAKA}

Babcock, P. (2009). The rational adolescent: Discipline policies, lawsuits, and skill acquisition. Economics of Education Review, 28(5), 551-560.

Bellizzi, J. A., \& Hasty, R. W. (2001). The effects of a stated organizational policy on inconsistent disciplinary action based on salesperson gender and weight. Journal of Personal Selling \& Sales Management, 21(3), 189-198.

Bower-Russa, M. E., Knutson, J. F., \& Winebarger, A. (2001). Disciplinary history, adult disciplinary attitudes, and risk for abusive parenting. Journal of Community Psychology, 29(3), 219-240.

Davis, S., DeZoort, F. T., \& Kopp, L. S. (2006). The effect of obedience pressure and perceived responsibility on management accountants' creation of budgetary slack. Behavioral Research in Accounting, 18(1), 19-35.

Hawken, L. S., Sandra MacLeod, K., \& Rawlings, L. (2007). Effects of the behavior education program (BEP) on office discipline referrals of elementary school students. Journal of Positive Behavior Interventions, 9(2), 94-101.

Helwig, C. C., To, S., Wang, Q., Liu, C., \& Yang, S. (2014). Judgments and reasoning about parental discipline involving induction and psychological control in China and Canada. Child Development, 85(3), 1150-1167.

Indraputra, T., \& Sutrisna, E. (2013). Disiplin, Motivasi, Budaya Kerja, dan Kinerja. Jurnal Administrasi Pembangunan, 1(3), 276-281.

Kinsler, J. (2013). School discipline: A source or salve for the racial achievement gap?. International Economic Review, 54(1), 355-383.

Lacoe, J., \& Steinberg, M. P. (2018). Rolling back zero tolerance: The effect of discipline policy reform on suspension usage and student outcomes. Peabody Journal of Education, 93(2), 207-227.

Laird, T. F. N., Shoup, R., Kuh, G. D., \& Schwarz, M. J. (2008). The effects of discipline on deep approaches to student learning and college outcomes. Research in Higher Education, 49(6), 469-494.

Lindblom-Ylänne, S., Trigwell, K., Nevgi, A., \& Ashwin, P. (2006). How approaches to teaching are affected by discipline and teaching context. Studies in Higher education, 31(03), 285-298.

Marchbanks III, M. P., Blake, J. J., Booth, E. A., Carmichael, D., Seibert, A. L., \& Fabelo, T. (2015). The economic effects of exclusionary discipline on grade retention and high school dropout. Closing the school discipline gap: Equitable remedies for excessive exclusion, 59-74.

McReynolds, L. S., \& Wasserman, G. A. (2008). Risk for disciplinary infractions among incarcerated male youths: Influence of psychiatric disorder. Criminal Justice and Behavior, 35(9), 1174-1185.

Qualls, R. (2014). The relationship between disciplinary practices in childhood and academic dishonesty in college students. College Student Journal, 48(3), 362-374. 
Singer, S., \& Smith, K. A. (2013). Discipline-based education research: Understanding and improving learning in undergraduate science and engineering. Journal of Engineering Education, 102(4), 468-471.

Suwondo, D. I., \& Sutanto, E. M. (2015). Hubungan lingkungan kerja, disiplin kerja, dan kinerja karyawan. Jurnal manajemen dan kewirausahaan, 17(2), 145-154.

USÓ-JUAN, E. S. T. H. E. R. (2006). The compensatory nature of discipline-related knowledge and English-language proficiency in reading English for academic purposes. The Modern Language Journal, 90(2), 210-227.

YE, F. Q., \& LIU, H. (2009). The Development of Advertising Dicipline and the Study Paradigm Shift. Journal of Fujian Normal University (Philosophy and Social Sciences Edition), (6), 31. 